\title{
ETHICS IN BUSINESS AND COMMUNICATION: COMMON GROUND OR INCOMMENSURABLE?
}

\author{
Tomas Kačerauskas
}

\section{Introduction}

The discourse - conversation - surrounding ethics has its roots in the Socratic and Platonic tradition, which displaced that of the preSocratic philosophers such as Thales and Anaximander. Taking a rationalist approach, i.e. the inseparability of ethics from knowledge, Socrates and Plato entirely changed the landscape in terms of the epistemological discourse. Plato (2006) develops the idea of Socratic rationalistic ethics and considers good (alongside beauty) and justice as fundamental to reality. Aristotle (2011) holds that wise decisions are an indication of a virtuous way of life and a social order that is just. Unsurprisingly, in his view ethics is the common, indissoluble link between individual activity and social relations. Similarly, for Thomas Aquinas (1948-1949), ethics encompasses rules that govern our actions and virtues, both of which are milestones for the individual. Immanuel Kant (1997) stresses the rationalistic principle of ethics by appealing to practical reason, i.e. reason as a guide to practical activity.

Is ethics in business and communication possible to achieve in practice? According to Peter Drucker, "there is neither a separate ethics of business, nor is one needed" (1981). However, since the time of antiquity, professional ethics has been a subject for discussion. For example, (Bauman, 2018) is one scholar among many who analyses the historic background to business ethics based on the Platonic leadership model. General ethics can be adapted to suit different contexts, and whilst there may be no particular need to formulate separate ethics, one such adaptation as professional ethics or ethics that pertain to business and communication.

Different approaches and relationships apply to the matter of business and communication ethics. For example, (Enderle,
2018) explores the relationship between business ethics and social capital, whereas (Helfaya, 2018) considers the ethical principles of regional business from a Muslim perspective. The work of (Ladkin, 2018) traverses business ethics with regard to aesthetics, and (San-Jose \& Retolaza, 2018) use certain Delphic methods as a framework to analyse ethics in the business world. The scholars speak about moral decision making (Nadurak, 2018), uncertainties associated with ethics (Holub, 2018), moral revolutions (Gonzalez, 2017), contemporary activities in the context of practical philosophy (Belas \& Belasova, 2017) etc.

In the contemporary discourse on ethics, numerous questions arise: Is ethics in business or communication deserving of a category in its own right? Is there such a thing as global universal ethics? Do ethical attitudes change in response to the evolving social context/ environment? Can we speak of ethical bases being immutable? How do we define ethical maxims in business - negatively or positively? What is the relationship between business ethics and other professional ethics, including those of communication, and what of the personal qualities and belief systems of a business leader? What is the relationship between ethics and social capital in contemporary society that is increasingly polarized? Moreover, do ethical principles change depending on cultural and/or religious differences?

It may be that business and communication reside in very different spheres, although it is fair to say that business would not be possible in the absence of certain communication such as advertising. How, then, do we make valid comparisons between business and communication with regard to ethics? What is the relationship between both general ethics and regions as business and communication ethics? Finally, if we compare business ethics 
with communication ethics, what does this reveal in each of them?

The paper consists of two parts. The first part presents the main problems of business ethics. The second part analyses the main issues of communication ethics and makes the comparison between business ethics and communication ethics.

This paper is based on an extensive review of discussions in the recent literature concerning business ethics. A critical approach has been applied towards the issues, and a historical approach applied by demonstrating the ethical ideas in the history of philosophy. The regional approach is used which appeals to such ethical regions as professional ethics as well ethics in the cultural rims. Whilst this paper draws on a wide range of opinions of scholars concerning business ethics, it makes no claim to be comprehensive. Additionally, the paper seeks to make reasoned criticisms of business and communication ethics.

By drawing out the comparison between business and communication ethics this paper provides additional insights and perspectives. Second, the paper adopts a critical approach rather than euphoric discourses concerning business and communication ethics that are typical of much of the current literature. Third, the relationship between global (universal) and local (regional) in ethical level is developed.

\section{Business Ethics: Main Problems}

In terms of business ethics there are different business discourses and different ethical approaches including regional (EU, US, Asia) or those based on different authorities. On the one hand, the associations that exist in business ethics attempt to unify the discourses, at least in a region. On the other hand, it expresses the demarcation of certain discourses in business ethics from others.

According to Enderle, the "task of business ethics is to enhance the ethical quality of decision making and action at all levels of business: at the personal (micro-), organizational (meso-), and systemic (macro-) levels. Faced with complex issues, business ethics must adopt a multilevel approach and account for the freedoms and constraints at each of these levels, as well as for the interrelationships between these levels" (2018, p. 620). San-Jose and Retalaza (2018) talk of the three levels of business ethics, i.e. micro (individual), meso (organizational view) and macro (systematic view). The aforementioned refer to the different ethical planes in individual, professional and global ethics. Yet, there are certain contradictions between these levels. Additionally, Ederle (2018) mentions natural, economic, human, social capital in relation to ethics, yet the place of creative capital is not clear. For the purposes of this article, we are not concerned with types of capital suggested by Bourdieu (1986), Putnam (2002), et al. The salient point to note is that social cohesion frustrates an individual and their creative initiatives, including initiatives in the realm of business. On the other hand, business tends to discount and exclude exceptional, inimitable ideas which are deemed to be inconsistent with group think that is commonly found among teams. Perhaps this is why Florida (2002) argues that creative capital and individual aspirations as being inconsistent with social capital.

The question is whether natural, economic, human and social capitals are not a kind of connecting channels while the general capital remains stable? For example, natural capital declines while economic capital increases and global warming is nothing more than the result of human economic activity. Similarly, social capital increases due to creative capital, which is not mentioned by Enderle. If so, it is impossible to increase all kinds of capitals. Unsurprisingly, business ethics deal with the limits of any kind of capital rather than increasing them. A similar situation is evident in the case of communication ethics.

Another important issue surrounding business ethics is "human rights conceptualized as public goods" (Enderle, 2018, p. 620). Generally speaking, the relationship between business and the public good is contradictory. On the one hand, business increases the public good by suggesting that commodities and services are for everybody, as well as engaging labouring (wo)men. On the other hand, business is narrowly focussed on those engaged in business. A strong case can be made for business ethics to soften such contradictions, although it is not entirely clear how this might work in practice. For example, if government intervenes to regulate business ethics then it is axiomatic that the latter have been subsumed into the juridical region. Ethics, including business ethics, functions only when 
it is autonomous from the juridical region but also regulation from "above". Much like I. Kant, many scholars speak about the so-called consciousness of the participants of the ethical region which extends to the realm of business. This approach might be deemed rationalistic and implies great harm caused to a particular business if a person engaged in that business violates ethical norms. Conversely, another approach would be aesthetic which appeals more to the individual, and their feelings and are consistent with their attitude towards ethics in general. We will return later to this aesthetic/ ethic approach as an alternative to Kantian rationalistic ethics.

If the issue of business ethics is to ensure "the creation of wealth as a combination of private and public wealth" (Enderle, 2018, p. 620), then what of the imperative to harmonize private and public spheres? For example, Kant (1997) suggests evaluating intentions rather than the result of certain actions. Beside this, any combination suggests the different weight of components. These differences reflect different attitudes towards the role of the individual in social development. For example, Plato (2006) neglects individuals in preference to wider society, while Hayek (1994) lays stress on deleterious consequences of neglecting society. Moreover, any creative intention often reasons the imbalance between private and social spheres.

Yet another important issue in business ethics is its relationship to human rights, and in this regard there is an on-going discussion concerning human rights in the history of thought. Do human beings have intrinsic inborn - rights as legal persons? And what priority can human rights assume to occupy? Despite certain 'lists' of human rights in the official institutions (UN, 2011), there has been little consensus until recently. If we are referring to the "universal normative standards for businesses and economies" (Enderle, 2018 , p. 627), is it not a kind of an extended metaphysical narration on the one hand, and a kind of globalism on the other? Is it not an attempt to level and to subordinate any initiatives in business despite their differences? In 1948, the Universal Declaration of Human Rights emerged from its prevailing political and historical context (the Second World War) but was, for the most part, a reluctant compromise. According to the United Nations Guiding
Principles for Business and Human Rights (UN, 2011), 30 human rights attach to business, including civil, political, economic, social, and cultural rights, and the right to development, although it says nothing about ethics. Perhaps human rights are an abstraction? Notwithstanding, ethics is deeply fundamental, and more so than any political declaration or agreement between representatives of nation states. Is ethics the result of a social contract?

Few would disagree that justice is a fundamental human right, which also extends to business activity and ethics. For example, justice suggests equal rights for those who are subject to the market to both ground and develop their business. Why should consumers not exercise the same rights when purchasing commodities, although this might be in contradiction with human rights? The right to a commodity depends on the purchasing power of the individual, so that if we level the incomes in order to ensure this right for the majority, we violate the rights of business and the creative minority. Revolutionary upheaval throughout history has witnessed the usurpation by the minority over rights to commodities hitherto exercised by the majority. This "right" usually leads to the displacement of the minority. Perhaps an alternative to violent upheaval is civil disobedience that follows from Rawls' (2003) theory of justice: an individual or a group is free to resist the unjust social order that tramples on injustice. What about the right of civil disobedience? Is it unethical?

The notion of "wealth" is another controversial notion related to business ethics, although we must first consider the meaning of wealth through the prism of richness, employment, creativity, openness, communicativeness. To illustrate, wealth measured by Gross Domestic Product (GDP) can be compared with the index of happiness, of which there are many. Typically, these might include, inter alia, the Happy Planet Index and the World Happiness Index. All of them affirm GDP as a factor in happiness, but no less important are other factors such as social support, healthy life, freedom to make life choice, generosity, and corruption. Paradoxically, as it may appear, developing countries such as Costa Rica or Mexico rank more highly than many richer, developed countries. What about the right to happiness? Despite one of the happiness factors being generosity in order to compensate 
for the inequalities, it also demonstrates the supremacy of generous (wo)man.

Some scholars (Musgrave, 1958; Samuelson, 1954; Samuelson, 1955) regard "Public goods" as non-exclusivity and nonrivalry, in which case business ethics should appeal to public goods in order to soften the inherent rivalry in business. This may be difficult in view of the fact that the development of business is based on exclusivity and rivalry. In general, creativity is a kind of non-standard thinking and of individualistic approach in all spheres including business, and scholars engage with social aspects of creativity (Manta, 2018; Zolfani et al., 2017). The relationship between individual creative aspirations and social environment is full of tensions and contradictions.

According to Enderle, "Social cohesion consists of three different, equally important components: (a) social inclusion (measured by such aspects of social exclusion as poverty, inequality and social polarization); (b) social capital (combining measures of trust-interpersonal and societal-with various forms of civic engagement; and (c) social mobility (measuring the degree to which people can or believe they can change their position in society)" (2018, p. 623). However, the requirement for business companies to be responsible often hides the negative public opinion formed by the politicians and the attempt to racket them. Finally, it leads to a negative business environment that turn negatively impacts social politics.

What of liberal values such as freedom, respect for diversity, and the rights of minorities? Contrary to Enderle (2018), such value as tolerance and equality do not automatically follow from the concept of liberalism. Again, once again we confront the matter of limits, including the limits of freedom in respect of the "Other" (Lévinas, 1979). However, the question is what about the "Other" for a businessperson. Is it the other businessperson, a customer or the anonymous poor?

As mentioned previously, scholars analyse the relationship between aesthetics and business ethics (Ladkin, 2018). Aesthetics with its subjectivity is in contrast to the "hyperrationalistic" approach to ethical argument. Balance, harmony, proportion and fitness have been considered as aesthetic categories (Waddock, 2014) in business ethics. In business management, "imaginative" and "emotional" (Abowitz, 2007) aspects have been highlighted, e.g. moral imagination in architectural practice (Collier, 2006). On the one hand, the aesthetic approach is inseparable from subjective decisions is a source of individual autonomy. On the other hand, it is a limitation of global ethical principles beyond place and time. Must global principles be falsified by the cases from regions including business regions like scientific theories - by new data (Popper, 1989)?

Beside this, ethics has been treated as "responsibility for our conceptual frameworks and their embedded assumptions" (Greenwood \& Freeman, 2018). However, it is not clear here what kind of conceptual frameworks has been discussed. We have seen that ethics and its version business ethics was been based on certain rationalistic, i.e. conceptual aspirations. As a result, the background to this argument presents as a vicious circle where ethics been defined as rational reasoning that in turn leads to ethical attitudes. On the other hand, both revolution and war are usually based on certain "conceptual frameworks" that ultimately lead to wholesale slaughter, which is contrary to ethics.

The same authors speak about sustainability management, the gist of which is: "advancing the environmental and social responsibilities of the firms for which they work" (Greenwood \& Freeman, 2018, p. 2). However, the discourse of sustainability reflects a systematic approach when autonomous regions have been treated as regions subordinated to a system. This would appear to satisfy ethical rationalism, although the discourse of sustainability and that of ethics face the same problem of metadiscourse, and much the same applies to the different communication traditions. It is only possible to overlook the different and even contradictory communication discourses on the level of metacommunication that requires other meta-metacommunication, and so on. Additionally, it supposes our privileged position in respect of communication or business ethics discourses. Is that assumption that we are able to see different traditions and systems "from above" really ethical?

According to Murthy (2018), the dimensions of corporate responsibility comprise: good governance, corporate social responsibility and environmental accountability. This begs the question: what is good governance? Furthermore, if business activity is solely 
focussed on profit and wealth maximization, why should managers make ethical obstacles for themselves? This appears contradictory although it is useful to muse if business ethics may be a relic of economic evolution, which may be one of the general ethical principles from the perspective of human evolution. With this in mind, Kant (1997) speaks of the ethical argument for God's existence, as opposed to the cosmological argument advanced by Thomas Aquinas (1948-1949). Kant's reasoning can be expressed in this way: if ethics is still alive despite the evolution of the human species towards being richer and more powerful, it can only be explained in terms of a Divinity.

Research into corporate social responsibility examines certain players (social groups) including stakeholders, customers and government. If we can speak about professional ethics, i.e. the ethics of certain social groups, then which of them should take precedence? If there is global ethics, how can we harmonize the narrow interests of a firm or even corporation and ethical attitudes of both a social group and whole society? The managers of corporations have in minds their employees' army that is argument for more general ethics based on the interests of this army. On the other hand, such an approach expresses a narrow ethical attitude that neglects society as a whole. An additional problem is the relationship between corporate responsibility and sustainable development, the discourse about which also covers the matter of entropy. For example, Cohen-Rosenthal (2004) develops the idea of that a system must die if the entire social environment is to emerge renewed, which is typical of the outcome of revolution. In other words, the idea of sustainable development may require unsustainable solutions.

Some authors (Barrette, 2006) speak about different levels of consciousness, the lowest level of which is an expression of our interest in financial stability, whereas the highest is service to humanity and the planet. This may be regarded in two ways as Kantian ethics: first, it expresses the rationalistic background of ethics; and secondly, it is about global humankind. From this, two problems arise that are closely intertwined, i.e. the extent of the rationalistic approach in contradistinction to the aesthetic, and local ethical regions, which includes geographic and their cultural peculiarities as well as professional and business ethics.
Murthy (2018) stresses the relationship between success and corporate responsibility. In other words, success rests on the social capital. However, the individual success remains inseparable from creative capital that contradicts to social one, according to Florida (2002). The pupil of social capital and of its authorities is nobody else as obedient soldier without any initiative that has been usually punished in a society with tough relations, i.e. with rich social capital. The cost of such obedience is the refusal of any creative aspirations including the sphere of business. The extreme case of strong social ties was Soviet society and the absence of private enterprise which was officially forbidden, giving rise to the general absence of business ethics.

Palazzo (2002), Enderle (1996), Mele (2008) and Resick et al. (2011) note differences in business ethics between the US, Europe and Asia, which suggests that the case for global business ethics is poorly made, or not made at all. Perhaps it is more an argument for regional ethics which rely on not only different cultural traditions but also the field of activity. What of the regions of business ethics and communication ethics? In Part 2, I will analyse the problems of communication ethics and further develop issues of business ethics.

\section{Communication Ethics: the Main Issues}

First, a consideration of different ethics from the perspective of the different discourses present in communication. Fiske (2010) asserts there are two communication schools (semiotic and process), whereas Craig and Muller (2007) appeal to seven communication traditions, which include rhetoric, semiotic, cybernetic, social-cultural, social-psychological, phenomenological, and critical. There are possibly more schools of thought regarding communication schools such as postmodern, feminist, biological, pragmatic, media, political, pedagogic, analytic etc. Can a universal set of ethics be applied to the abovementioned communications and business practice?

Communication ethics coexists within the limits of communication. We have already discussed a similar situation regarding the inseparability of business ethics from the limits of the business. The question concerning global ethics, however, relates to metacommunication, because if there be such a thing as an 
encompassing metacommunication, then there could be related ethics, which are global. If we allow that there are second level communications encompassing a number of communication schools, the question will arise concerning the third level metacommunication, leading to what Aristotle called regressus ad infinitum - infinite regress. Such a global communication would be somewhat oppressive for diverse discourses, obliging them to fit the straightjacket of uniformity and homogeneity. This trend emerged in the closing decades of the seventeenth century and later evolved into what we regard as propaganda. Metacommunication understood in this sense is unethical in principle. If this is the case, (and if global ethics serves metacommunication irrespective at what level), such an ethics is not, and can never be, ethical.

This raises a number of considerations, the first of which is that metacommunication is something entirely different. Paradoxically, we would claim that it is not related to some divinely inspired view of the distinct traditions of communication, but to practical activity, which includes dialogue as practical engagement. Second, there is an assumption that diverse communication discourses and activities exist within different environments, schools and societies that may have distinctive ethical principles of their own. On the other hand, we can classify different ethics according to types of communication. Suppose that we accept Flusser's (2007) classification and speak of a pyramidal (adherence to subordination), amphitheatric (adherence to the direction of communication), and similar ethics, then how can there be a general (global) ethics among the diverse activities of communication? Moreover, ethics is the function, which appears in practical activity. Business, on the one hand, and everyday communication, on the other, is one such practice.

Kant (1997) named this sphere as 'practical reason' and formulated the general rule of action as to: "act in a way that your action could become a general rule". Let us therefore try to formulate this maxim with respect to communication characteristics, i.e., "communicate in such a way that your communication would become a general rule". In business ethics, the first maxim would be as follows: "make business in such a way that your business activity would become a general rule". Does this maxim result in the idea of business as general practice? Although different human activities share certain attributes with business, the latter does not cover all possible practices. If we define business in part as accumulating financial capital, such meaningful activities as charity dissipate such capital, which is clearly a limitation to the pursuit of business. Perhaps it is more do with Kantian maxims that in a paradoxical way are too general to be realized in everyday practice.

If we accept the aforementioned ethical maxim, it would be unethical for us to communicate uniformly despite the variety of ways and standards of communication. One of the ways of alternative communication is non-communication, whilst another is distorted communication. Both of these play an important role in practical activity. Accordingly, a first maxim of communicative ethics should be "do not aim at uniform global communication". Similarly, we can say "do not make business in the same way as many make". This maxim helps to avoid unnecessary rivalry and even helps to maximize the profit. On the other hand, the first maxim satisfies the trends of creative society. The second maxim flowing from the first would be "do not seek communication at any price". Similarly, we can formulate "do not seek business at any price". There are situations that require neither communication nor business, a kind of situationalism (Debord, 1994) that satisfies the idea of metacommunication in everydayness. Both maxims are negative, i.e. formed negatively, indicating what one should not do.

Instead, the maxim of communication ethics should be formulated in the positive: "know the limits of your communication". Similarly, we can formulate: "know the limits of your business", which could be used to define the ethical content of global communication, although we need to recognise that in a global sense every communication is limited, and that there is no such thing as global communication. In other words, the basic rule of communication ethics is: do not claim to global communication, and transgression of this rule leads to propaganda, which is also an obstacle to communication. Recent experience of totalitarian society across Europe and the former Soviet Union shows that propaganda becomes pseudocommunication, which permeates everywhere and everything. The people, however, neither believe this rhetoric nor trust government's attempts to usurp the private sphere. It follows 
that propaganda (global communication) is totalitarian oppression fully realized. An opposite "causal" relationship can be assumed, too: the claim to global communication gives birth to totalitarian oppression. What can this tell us about global business?

Ethics in global communication is only possible to the extent to which it protects from global communication, and enhances local (social, individual) ethics, and, put simply, is antiimperialistic. Of course, common human ethical principles must not to be discarded, i.e., do not kill, and tell the truth. Communicative ethics seem to be local, regional in that they reside in some layered regions wherein the individual, society and humanity intersect. Primarily, it is a defence against their subordination, one over the other, insisting that the voice of an individual must be heard. Universal communication ethics finds itself in opposition to a system's ethics as a way of incorporating the individual into the standards of a system (including its ethical standard). The word "universal" signifies that universally the individual's voice must be taken into account, which blends to form what can be thought of as a form of social choir. In this case, so-called systematisers are least concerned with global ethics, but merely want to enhance a global communication system.

We can extend these considerations further to global business that stifles, then kills, small local business in the regions and where corporate ethics is a contradiction. If corporates grow their scale at global business by oppressing regional enterprises, they also try to co-opt their employees into participating in the overall framework of the corporate objective. Thus, by seeking global power, the corporates ignore or falsify universal ethical attitudes by orienting paradoxically towards departmental rules of behaviour. Is there a kind of regional ethics within global enterprise?

Media ethics is the counterpart of communication ethics. An examination of global communication ethics discloses the question of relationships among media. Do the confluence and symbioses of media mean that they incorporate one another while developing into one global medium? Does this mean that the days of the family of media are numbered? If so, there will be nothing left of that resembles what most people understand by the term, family. Does one medium mean that all of us disappear into the system as parts?

\section{Conclusions and Discussions}

Any discussion of business and communication ethics poses questions about the nature of the relationship between universal ethics and regional ethics, which must include professional ethics. If there are general ethical rules, then why do we need regional ethics, and vice versa? If we have professional ethics, do we still need general ethics? If we speak of the different regional (professional) ethics such as business and communication ethics, on what basis can we compare these ethics?

The on-going conversation about business ethics raises contentious issues and is invariably controversial. There are scholars who stress the primacy of social cohesion, but the latter frustrates individual and creative initiatives that are part and parcel of business activity of a person or organization. The demands of business are such that exceptional ideas may be inconsistent with strict control necessary to operate within a particular social environment. Ethics and its professional regions therefore need to remain independent of juridical region and regulation.

Arguably, human rights are integral to business ethics, yet there is still no consensus about precisely which human rights apply, or are being impacted. As yet, official bodies, including the United Nations, have no definition of business ethics, which may be widely regarded as somewhat abstract. Whatever the case, ethics resides at a fundamental level that extends beyond the merely political.

Certain scholars argue that the existence of agreed business ethics can dampen the rivalry inherent in business by appealing at a general level as pro bono - for the public good. This may be somewhat ambitious since business is competitive and predicated on exclusivity and rivalry. Finally, the requirement for business companies to be responsible often hides the attempt to racket them. This leads to negative business environment that has in turn negative impact on social politics.

The limits of freedom in respect of the "Other" is yet another issue in business ethics, although it remain unclear as to what is the "Other" in business. Is it the 'other' business person, a customer or the anonymous poor? Since the interests of each party may different the result in every case will likewise be different.

It also appears to be the case that taking a subjective, aesthetic approach is inconsistent 
with an ethic rationalistic approach. However, it could be related namely with individual autonomy important for ethics. Beside this, it is a limitation of global ethical principles beyond certain localities.

There is also the question of ethics in business evolution, because if the quest for profit and greater wealth overrides all other considerations, then why should managers create ethical obstacles to the achievement of these goals? Indeed, are business ethics simply a relic of economic evolution? Much the same can be said for universal ethics, which can be regarded as a sort of relic viewed from the perspective of human evolution.

If we treat professional ethics as ethics of certain social group, which of these should we choose? If we accept global ethics, how can the narrow interests of a firm or even corporation and ethical attitudes of both a social group and whole society be harmonized? If scholars explore the differences in business ethics in US, Europe and Asia, is there an argument against global business ethic, and is it an argument for regional ethics?

What concerns most about communication ethics? Firstly, we recognise that different ethics attach to different communication discourses, yet is there an ethics that covers all communications and even business practice? Ifthere is an encompassing metacommunication, what of its ethics, which could be called global? By nature, global communication would be oppressive for diverse discourses, forcing them into "straight", "homogeneous" and "uniform" jackets, which would be nothing less than propaganda. Is metacommunication understood in this way ethical in principle? If propaganda as global communication is a realization of totalitarian oppression, what about the opposite "causal" relationship? Does the claim to global communication give birth to totalitarian oppression? Whether is it possible to say about global business?

\section{References}

Abowitz, K. K. (2007). Moral perception through aesthetics engaging imaginations in educational ethics. Journal of Teacher Education, 58(4), 287-298. https://dx.doi. org/10.1177/0022487107305605.

Aristotle. (2011). Nicomachenian Ethics. (R. C. Bartlett \& S. D. Collins, Trans.). Chicago: University of Chicago Press.
Barrette, R. (2006). Building a value driven organization: A whole system approach to cultural transformation. London: Routledge.

Bauman, D. C. (2018). Plato on virtuous leadership:An ancient model for modern business. Business Ethics Quarterly, 28(3), 251-274. https://dx.doi.org/10.1017/beq.2017.31.

Belas, L., \& Belasova, L. (2017). Contemporary society in the context of Kant's practical philosophy. Filosofija. Sociologija, 28(3), 204-211.

Bourdieu, P. (1986). The forms of capital. In J. G. Richardson (Ed.), Handbook of theory and research for the sociology of education (pp. 241-258). New York: Greenwood Press.

Cohen-Rosenthal, E. (2004). Making sense out of industrial ecology: a framework for analysis and action. Journal of Cleaner Production, 12(8-10), 1111-1123. https://dx.doi. org/10.1016/j.jclepro.2004.02.009.

Collier, J. (2006). The art of moral imagination: Ethics in the practice of architecture. Journal of Business Ethics, 66(2-3), 307-317. https://dx.doi. org/10.1007/sl0551-005-5600-4.

Craig, R. T., \& Muller H. L. (Eds.). (2007). Theorizing communication: Readings across traditions. London: Sage.

Debord, G. (1994). The Society of the Spectacle. (D. Nicholson-Smith, Trans). New York: Zone Books.

Drucker, P. (1981). What is business ethics? The Public Interest, April, 18-36.

Enderle, G. (1996). FOCUS: A comparison of business ethics in North America and Continental Europe. A European Review, 5(1), 33-46. https://doi.org/10.1111/j.1467-8608.1996.tb00130.x.

Enderle, G. (2018). How Can Business Ethics Strengthen the Social Cohesion of a Society? Journal of Business Ethics, 150, 619-629. https://dx.doi.org/10.1007/s10551016-3196-5.

Fiske, J. (2010). Introduction to communication studies. Abingdon, Oxon: Routledge.

Flusser, V. (2007). Vorlesungen zur Kommunikologie. In Kommunikologie (pp. 233-235). Frankfurt am Main: Fischer Taschenbuch Verlag.

Gonzalez, A. M. (2017). The pending revolution: Kant as a moral revolutionary. Filosofija. Sociologija, 28(3), 194-203.

Greenwood, M., \& Freeman, R. E. (2018). Deepening Ethical Analysis in Business Ethics. Journal of Business Ethics, 147(1), 1-4. https://dx.doi.org/10.1007/s10551-017-3766-1. 


\section{Business Administration and Management}

Hayek, F. A. (1994). The Road to Serfdom. Chicago: University of Chicago Press.

Helfaya, A., Kotb, A., \& Hanafi, R. (2018). Qur'anic Ethics for Environmental Responsibility: Implications for Business Practice. Journal of Business Ethics, 150(4), 1105-1128. https://dx.doi.org/10.1007/s10551016-3195-6.

Holub, G. (2018). Human enhancement ethics and uncertainty. Filosofija. Sociologija, 29(1), 70-78.

Kant, I. (1997). Critique of practical reason. (M. Gregor, Trans.). Cambridge: Cambridge University Press.

Lévinas, E. (1979). Totality and infinity: An essay on exteriority. (A. Lingis, Trans.). Hague/ Boston/London: Martinus Nijhoff Publishers.

Manta, A. (2018). Demystifying creativity: an assemblage perspective towards artistic creativity. Creativity Studies, 11(1), 85-101. https://doi.org/10.3846/cs.2018.542.

Melé, D. (2008) Business ethics: Europe versus America. In Leadership and business ethics (pp. 13-27). Springer: The Netherlands.

Musgrave, R. A. (1958). The theory of public finance. New York: McGraw-Hill.

Nadurak, V. (2018). Two types of heuristics in moral decision making. Filosofija. Sociologija, 29(3), 141-149.

Palazzo, B. (2002). US-Americanand German business ethics: an intercultural comparison. Journal of Business Ethics, 41(3), 195-216. https://doi.org/10.1023/A:1021239017049.

Plato. (2006). The Republic. (R. E. Allen, Trans.). New Haven: Yale University Press.

Popper, K. R. (1989). Logik der Forschung. Tubingen: J. C. B. Mohr (Paul Siebeck).

Putnam, R. D. (2002). Bowling alone. The collapse and revival of American community. New York, London, Toronto, Sydney, Singapore: Simon \& Schuster.

Resick, C. J., Martin, G. S., Keating, M. A., Dickson, M. W., Kwan, H. K., \& Peng, C. (2011). What ethical leadership means to me:
Asian, American, and European perspectives. Journal of Business Ethics, 101(3), 435-457. https://doi.org/10.1007/s10551-010-0730-8.

Rawls, J. (2003). A theory of justice. Cambridge: The Belknap press of Harvard university press.

Samuelson, P. A. (1954). The pure theory of public expenditure. Review of Economics and Statistics, 36(4), 387-389. https://doi. org/10.2307/1925895.

Samuelson, P. A. (1955). Diagrammatic exposition of a theory of public expenditure. Review of Economics and Statistics, 37(4), 350-356. https://doi.org/10.2307/1925849.

Thomas Aquinas. (1948-1949). Summa theologica. (Fathers of the English Dominican Province, Trans.). New York: Benziger Bros.

United Nations (UN). (2011). Guiding principles on business and human rights: Implementing the United Nations "protect, respect and remedy" framework. Report of the Special Representative of the SecretaryGeneral on the issue of human rights and transnational corporations and other business enterprises. John Ruggie. Human Rights Council. Seventeenth Session. A/HRC/17/31.

Waddock, S. (2014). Wisdom and responsible leadership: Aesthetic sensibility, moral imagination, and systems thinking. In D. Koehn \& D. Elm (Eds.), Aesthetics and business ethics (pp. 129-147). Dordrecht: Springer.

Zolfani, S. H., Maknoon, R., \& Juzefovic, A. (2017). Leadership, music and creative society: A philosophical analysis of possible future. Filosofija. Sociologija, 28(1), 20-28.

Prof. Tomas Kačerauskas, Ph.D. Vilnius Gediminas Technical University Faculty of Creative Industries Department of Philosophy and Cultural Studies Lithuania tomas.kacerauskas@vgtu.It 


\section{Abstract}

\section{ETHICS IN BUSINESS AND COMMUNICATION: COMMON GROUND OR INCOMMENSURABLE?}

\section{Tomas Kačerauskas}

Do business and communication share common ethical ground or are they incommensurable notions? This paper explores the on-going conversation surrounding the role of ethics in business and communication and related practical issues. A critical approach has been applied towards the issues, and a historical approach applied by demonstrating the ethical ideas in the history of philosophy. The regional approach is used which appeals to such ethical regions as professional ethics as well ethics in the cultural rims. Through the analysis of the relationship between global and local ethics in business and communication, the paper examines problems and issues with particular reference to meta-discourse, media, market, and, significantly, propaganda. Part 1 considers the main problems germane to business ethics, which is followed by analysis of the issues pertaining to communication ethics. Part 2 draws a comparison between the two and develops a critical approach. Kantian analysis is applied to the generally accepted maxims of ethics in business and communication. Such maxims include the reminder that: "uniformity in global communication is not possible"; and "avoid conducting business by slavishly copying others". Furthermore, "never seek either business or communication at any price". Put simply, the aforementioned imply something that is both simple and direct: "know the limits of your communication" and "know the limits of your business". The paper adopts a critical approach rather than euphoric discourses concerning business and communication ethics that are typical of much of the current literature. Beside this, the relationship between global (universal) and local (regional) in ethical level is developed.

Key Words: Business ethics, communication ethics, corporation ethics, metacommunication, ethical maxims.

JEL Classification: A12, A13.

DOI: 10.15240/tul/001/2019-1-005 